\title{
Analysis of Salary and Reward Effect toward Performance of Administrative Employees at Universitas Muhammadiyah Purwokerto
}

\author{
Purnadi \\ Universitas Muhammadiyah Purwokerto \\ Purnadi1972@gmail.com
}

\begin{abstract}
This research is to know the effect of salary and reward or appreciation toward performance variable and also to know the most influential variable to the performance of administrative employees of Universitas Muhammadiyah Purwokerto. The hypothesis tested in this research are salary and reward or appreciation toward the performance of UMP administration personnel based on data analysis. It is known that salary and reward or appreciation variables completely and partially have a significant influence on employees' performance. This means that the better attributes incorporated in the variable of salary and rewards or appreciation leads to employees' high performance. This is confirmed by the result of calculation of the value of $F$ and $t$ arithmetic greater than the value of $F$ and $t$ table. Based on data analysis, it is known that the value of the coefficient variable of the reward variable is greater than the value of the other variables, that means the reward or appreciation variable has the greater influence compared to the other variables on the employees' performance.
\end{abstract}

Keywords: salary and rewards, employees' performance.

\section{INTRODUCTION}

The intense competition in the world of education requires all educational institutions to always find many ways to survive even to develop the organization. Therefore, the role of employees in an effort to achieve the competitive advantage of an organization is very important. An organization can win the competition through making the best use of resources that have good ability, skill and job knowledge.

Universitas Muhammadiyah Purwokerto (UMP) is an institution founded by the Muhammadiyah organization engaged in education, which aims to produce outstanding, modern and Islamic scholars. UMP is located in Purwokerto, The Province of Central Java, previously known as IKIP Muhammadiyah Purwokerto established on April 5, 1965 that is the branch of IKIP Muhammadiyah Surakarta. UMP in doing its activities is supported by its employees. Therefore, employees are important asset that must be taken into account because their roles are determined to the successful achievement of the goals set by the UMP.
One of efforts that can be taken by the organization in achieving the goals is providing job satisfaction in order to improve employees' performance. It cannot be denied that job satisfaction will be accomplished when the needs of employees are met, in this condition employees will make a concentrated effort to finish the work, indeed, this is effective to their job performance. In other words, improving the quality of human resources (HR) will encourage employees to carry out every available job to be well managed so as to deliver high-performing human resources.

Thus, employee performance is an area of concern for all companies, regardless of whether they seek profit or not [1], while the restrictions on performance are as output notes that are derived from the function of a particular job or activity during a certain period. States the performance is the work that can be achieved by a person or group of people in an organization both quantitatively and qualitatively, in accordance with the authorities and duties of each responsibility in an effort to achieve the relevant organizational goals legally, based on law and in accordance with morals and ethics. In the overall performance of the organization is very important to maintain an efficient and effective workforce [3].

So it can be concluded that the performance is the result of work in quality and quantity achieved by the employee in carrying out his duties in accordance with the responsibilities given to him. Workers who work effectively, efficiently, productively and qualified as job standards are successful workers if otherwise stated otherwise.

The benefits of implementing performance management are to support efforts in developing a work culture, changing the mindset which is oriented on process and work, binding the work unit or related employees to carry out the management functions correctly, facilitating identification of which stages are weak and must be improved, avoiding the accumulation of work at one particular stage that allows the engineering of the plan and the reality of the performance targets.

High performance is a hope for all organizations as it is the determinant to organizational goal achievement and organizational growth. However, to achieve all this, internal and external condition of employees must be taken into serious account, importantly from the internal 
organization. Internal condition of the organization one of them is about job facilities.

Salary is very important for employees' performance. Salary is one of the important things for every employee who works in a company, because the amount of salary earned, a person can meet the needs of his life.

Salaries can be an important factor in determining whether a person will come to work on a particular day. Early delays and returns from work will also cost the same as absenteeism and are often caused by the same factors. Early absenteeism, delays, and early work can be controlled using hourly salary or average monthly salary. However, the hourly salary can result in discontent among professionals because it is a rough worker who is associated with such salary. The hourly salary system can also charge administrative costs due to the additional burden of record keeping.

Other problems may arise for inadequately paid employees who are trapped in a job due to labor conditions or the extent of knowledge, expertise and ability. Anticipating payment satisfaction will affect employee's decisions about how hard he will work.

The concept of appreciation or reward cannot be separated from the concept of motivation. Thus, the award is one of the factors that led to motivation. In mapping the level of needs, Maslow asserted that the need for an award is included in the fourth level of ego needs consisting of physiological needs; it is the most basic needs people have. The need for security is the need for protection from danger or loss, social needs are necessities such as affiliation and receiving love and friendship, ego needs related to one's self-respect with respect to one's reputation.

The gift management is one of method used by organizations to attract and retain appropriate employees and facilitate them to improve their performance [4]. Giving rewards to employees on the basis of achievement, rank, experience and so on.

Mentions that organizations should focus on changing the intrinsic nature and content of the work that will increase employees' motivation as employees will get more independent and challenging works and responsibilities [4]. The direct and warm greeting may be enough to make the employee agile and make a positive boost for the employee to give his best effort. It is also recommended to give training and other award practices to improve employees' performance [5]. Therefore, good salaries, housing, and health benefits promote the security of an organization's work [6].

Several previous studies that have been linked to this research problem will be described below. The studies will also be used as reference materials to understand the influence of variables.

The Influence of Salaries and Incentives on Employees' Performance and Organizational Citizenship Behavior (OCB) at Grand Clarion Hotel Makassar". The analytical method used is the path analysis of 50 employees. The result of the research is known that the influence of salary and incentive has a significant effect to the effectiveness of job implementation. Of the above variables, incentives have the most powerful influence on employees' performance.

The method of analysis used is quantitative descriptive method. Of the above variables, incentives have the most powerful influence on employees' performance [8]

The research approach used is qualitative approach. The sampling technique is using saturated sampling technique amounted to 70 people [9]. From the above variable, awards have the most powerful influence on employees' performance.

The purpose of this research is to know and analyze the influence of job facility, salary, leadership, and reward variables partially or simultaneously to the performance of UMP administrative staff and to know and analyze the most influential variables of job facility, salary, leadership, and reward variables performance of UMP admission staff.

\section{METHODS}

In this study, the object of research is the administrative employees of Universitas Muhammadiyah Purwokerto. This study uses data gathered from respondents who were provided a written response to a given statement. The types of data used in this study are:

Primary Data

Primary data in this research are respondents' opinion about salaryand reward or appreciationtoward performance of employees gathered from their response to statements in the questionnaires.

Secondary Data

The secondary data in this study gathered indirectly through intermediaries (obtained and recorded by others). In this study, the secondary data in question is data regarding the general description of UMP administrative staff. The data measurement technique used is Likert scale. This technique is a scaling of attitude statements that use response distribution as a basis for determining the scale value.

Furthermore, the choice of respondents' answers is scored. The score given for each response is in the range of 1 to 5 with a choice of answers consisting strongly agree (SS), agree (S), neutral (R), disagree (TS), and strongly disagree (STS). The population in this research is UMP administrative employees.

In this research, there are 3 variables: 2 independent variables consisting of salary $\left(\mathrm{X}_{1}\right)$, reward or appreciation $\left(\mathrm{X}_{2}\right)$, and 1 dependent variable is performance (Y). Indicators used for each variable.

\section{RESULT}

The population in this study is all the employees of UMP. The data in this study was obtained by distributing questionnaires, which amounted to 100 questionnaires. job facilities has a positive effect on the performance of administrative staff. This result can be seen from the coefficient of reward value of 0.251 and a significant value of 0.000 . This means that existing facilities in a company can improve the performance of administrative 
work. To foster interest in the work, it needs good facilities and infrastructure.

Table 1. Regression analysis results

\begin{tabular}{lccc}
\hline Model & $\begin{array}{c}\text { Unstandardized } \\
\text { Coefficients } \\
\text { B }\end{array}$ & T & Sig. \\
\hline (Constant) & 5,692 & 2,930 & 0,004 \\
R & 0,251 & 4,948 & 0,000 \\
S & 0,069 & 1,625 & 0,108 \\
\hline
\end{tabular}

\begin{tabular}{llll}
\multicolumn{4}{c}{ ANOVA $^{\mathrm{a}}$} \\
\hline Model & $\mathrm{F}$ & Sig. \\
Regression & 11,680 &, $001^{\mathrm{b}}$ & \\
Residual & & & \\
\hline Total & & & \\
\hline
\end{tabular}

a. Dependent Variable: KKA

b. Predictors: (Constant), R, S,

\section{Hypothesis Test Results}

The result of data analysis shows that salary variable has no effect on the performance of administrative staff;it can be seen on significance value for more than 0,05 $(0,108)$. This means that the amount of the salary does not affect the performance of administrative employees. This could be due to the work patterns in the educational environment that are not very varied in its types of work.

\section{REFERENCES}

[1] Idrees, etc, "Effect of salary, training anmotivation on job performance of employees 2015,"

[2] Moeheriono. "Competency Based Performance Measurement”. Jakarta: Raja Grafindo Persada. . 2012

[3] Aslam, etc, "Impact of Compensation and Reward System on the performance of an organization : An Empirical Study on Banking Sector of Pakistan. 2015

[4] Njanja, etc, "Effect of Reward on Employee Performance : A Cace of Kenya Power and Lghting Company Ltd, Nakuru Kenya”. 2013

[5] Njorogie, etc, "Influence of Compensation and Reward on Performance of Employees at Nakuru Country Government". 2015

[6] Wasiu, etc, "Reward System and Employees Performnce in Lagos State (A Study of Selected Public Secondary Schools)",. 2014

[7] Haeruddin, "The Influence of Salaries and Incentives on Employee Performance and Organizational Citizenship Behavior (OCB) at Grand Clarion Hotel Makassar"). 2017

[8] Subianto, "The Influence of Salaries and Incentives on Employee Performance PT. SerbaMulia Auto in West Kutai. 2016

[9] Prabu, Wijayanti, "The Influence of Awards and Motivation on Employee Performance (Study On Sales Division of PT United Motors Center Suzuki Ahmad Yani Surabaya)". 2016 